\title{
Hypomagnesemia Induced by Long-Term Treatment with Proton-Pump Inhibitors
}

\author{
Simone Janett, ${ }^{1}$ Pietro Camozzi, ${ }^{1}$ Gabriëlla G. A. M. Peeters, ${ }^{1}$ \\ Sebastiano A. G. Lava, ${ }^{2}$ Giacomo D. Simonetti, ${ }^{1,2}$ Barbara Goeggel Simonetti, ${ }^{1,3}$ \\ Mario G. Bianchetti, ${ }^{1}$ and Gregorio P. Milani ${ }^{4}$ \\ ${ }^{1}$ Pediatric Department of Southern Switzerland, Ospedale San Giovanni, 6500 Bellinzona, Switzerland \\ ${ }^{2}$ Pediatric Nephrology, Children's Hospital and University, 3010 Bern, Switzerland \\ ${ }^{3}$ Pediatric Neurology, Children's Hospital and University, 3010 Bern, Switzerland \\ ${ }^{4}$ Pediatric Emergency Department, Foundation IRCCS Ca' Granda Ospedale Maggiore Policlinico, 20122 Milan, Italy \\ Correspondence should be addressed to Mario G. Bianchetti; mario.bianchetti@pediatrician.ch
}

Received 22 December 2014; Accepted 16 April 2015

Academic Editor: Haruhiko Sugimura

Copyright (C) 2015 Simone Janett et al. This is an open access article distributed under the Creative Commons Attribution License, which permits unrestricted use, distribution, and reproduction in any medium, provided the original work is properly cited.

\begin{abstract}
In 2006, hypomagnesemia was first described as a complication of proton-pump inhibitors. To address this issue, we systematically reviewed the literature. Hypomagnesemia, mostly associated with hypocalcemic hypoparathyroidism and hypokalemia, was reported in 64 individuals on long-term proton-pump inhibitors. Hypomagnesemia recurred following replacement of one protonpump inhibitor with another but not with a histamine type-2 receptor antagonist. The association between proton-pump inhibitors and magnesium metabolism was addressed in 14 case-control, cross-sectional studies. An association was found in 11 of them: 6 reports found that the use of proton-pump inhibitors is associated per se with a tendency towards hypomagnesemia, 2 found that this tendency is more pronounced in patients concurrently treated with diuretics, carboplatin, or cisplatin, and 2 found a relevant tendency to hypomagnesemia in patients with poor renal function. Finally, findings likely reflecting decreased intestinal magnesium uptake were observed on treatment with proton-pump inhibitors. Three studies did not disclose any relationship between magnesium metabolism and treatment with histamine type- 2 receptor antagonists. In conclusion, proton-pump inhibitors may cause hypomagnesemia. In these cases, switching to a histamine type-2 receptor antagonist is advised.
\end{abstract}

\section{Introduction}

First introduced in the late 1980s, proton-pump inhibitors are widely used for the management of conditions related to gastric acid secretion such as duodenal and gastric ulcer, reflux esophagitis, and gastroesophageal reflux disease [1].

The cases of two patients developing severe hypomagnesemia along with hypocalcemia and hypokalemia while being on long-term treatment with a proton-pump inhibitor and resolution after withdrawal were first described in 2006 [2]. Following the initial recognition, the association has been subsequently confirmed in various reports [3]. We systematically reviewed and analyzed the available literature. Our aims were to describe in detail this electrolyte abnormality, to address the underlying mechanisms, and to warn physicians about its occurrence.

\section{Methods}

Between May and October 2014, two of the authors (Simone Janett, Pietro Camozzi) independently conducted a computer-based research of the terms "proton-pump inhibitor[s]," "dexlansoprazole," "omeprazole," "esomeprazole," "lansoprazole," "pantoprazole," "rabeprazole," and "hypomagnes[a]emia" or "magnesium" in the U.S. National Library of Medicine database and in the Web-based Google search engine. For this purpose, we used the principles established by the UK Economic and Social Research Council guidance on the conduct of narrative synthesis and on the Preferred Reporting Items for Systematic Reviews and Meta-Analyses statement. Reports available as an article or as a letter in Dutch, English, French, German, Italian, Portuguese, or Spanish were retained for the analysis. To ensure that 
the search included all published cases, cross-citation screening was manually performed in the references of the included articles. Poorly documented case reports and cases with electrolyte abnormalities secondary to proton-pump inhibitor associated kidney injury were not included [4].

From each individually described patient with hypomagnesemia $(<0.75 \mathrm{mmol} / \mathrm{L})$ on proton-pump inhibitor treatment, we made attempts to obtain the following data: gender; age; details and duration of medication; concurrent conditions or management with drugs inducing hypomagnesemia; and laboratory findings regarding magnesium (including changes after withdrawal and rechallenge with a different proton-pump inhibitor or with a histamine type- 2 receptor antagonist), calcium, parathyroid hormone and potassium blood levels, and urine magnesium excretion. From casecontrol, cross-sectional studies, we collected the following information: study setting; year of publication; origin of the report; number of patients and details; magnesium level; comorbidities and concurrent medications. Finally, we reviewed the United States Food and Drug Administration data on hypomagnesemia as adverse event reported during the use of proton-pump inhibitors.

Numerical data are presented as median and interquartile range and categorical data as relative frequency. Linear regressions with the rank correlation coefficient $r_{s}$ were performed for analysis. Significance was assumed when $P<$ 0.05 .

\section{Results}

3.1. Search Results. The initial search revealed 534 publications, of which 260 remained after excluding duplicates (Figure 1). Ninety were reviewed in detail and 56 retained for the final analysis. Four pertinent reports were found in the references of the mentioned reports. Hence, in the final analysis [2,5-63], we included a total of 60 reports (48 in English, 6 in Spanish, 3 in French, 1 in Dutch, 1 in German, and 1 in Italian) from the United Kingdom $(N=12)$, the United States of America $(N=9)$, Spain $(N=7)$, the Netherlands $(N=4)$, Brazil $(N=3)$, France $(N=3)$, Italy $(N=3)$, Switzerland $(N=3)$, Australia $(N=2)$, Belgium $(N=2)$, Canada $(N=2)$, Germany $(N=2)$, Korea $(N=2)$, Argentina $(N=1)$, Greece $(N=1)$, Israel $(N=1)$, Japan $(N=1)$, New Zealand $(N=1)$, and Turkey $(N=1)$.

They were 45 reports detailing individual cases [2,19-62], 14 case-control, cross-sectional studies [5-18] and one report based on the United States Food and Drug Administration data [63]. The case of a Spanish patient reported twice in the literature was considered only once $[33,34]$.

3.2. Individual Cases. The 45 reports detailing cases of proton-pump inhibitor associated hypomagnesemia included a total of 64 individual cases. The characteristics of the patients (30 male and 34 female subjects) appear in Table 1. The age of $53(83 \%)$ of the 64 patients ranged between 50 and 80 years. Hypomagnesemia was rather severe: it ranged between 0.03 and 0.71 , with median $0.21 \mathrm{mmol} / \mathrm{L}$ and was $\leq 0.50 \mathrm{mmol} / \mathrm{L}$ in $62(97 \%)$ cases. The

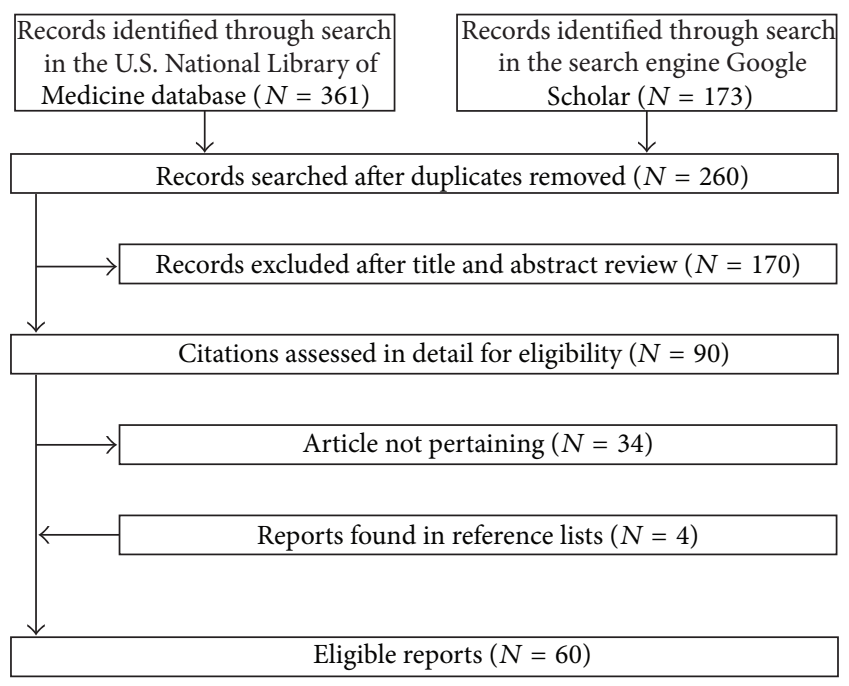

FIGURE 1: Flowchart of the literature search process. Five of the 60 eligible reports had been identified exclusively from the Web-based search engine Google Scholar.

TABLE 1: Clinical and laboratory findings in 64 patients with hypomagnesemia $(<0.75 \mathrm{mmol} / \mathrm{L})$ while being on long-term management with a proton-pump inhibitor. Numerical data are presented as median and interquartile range (which extends from the value at centile 25 to that at centile 75 and includes half of the data points) and categorical data as relative frequency.

\begin{tabular}{|c|c|}
\hline Age, years & $66[59-73]$ \\
\hline 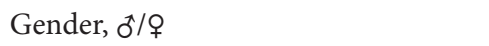 & $30 / 34$ \\
\hline Circulating magnesium level, $\mathrm{mmol} / \mathrm{L}$ & $0.24[0.15-0.30]$ \\
\hline $\begin{array}{l}\text { Duration of treatment with } \\
\text { proton-pump inhibitor, years }\end{array}$ & $4[3-10]$ \\
\hline $\begin{array}{l}\text { Urinary magnesium excretion, } \\
\text { low/normal }\end{array}$ & $42 / 0$ \\
\hline Circulating calcium level, low/normal & $58 / 2$ \\
\hline $\begin{array}{l}\text { Parathyroid hormone level }{ }^{\ddagger} \text {, } \\
\text { low-normal/high }\end{array}$ & $42 / 2$ \\
\hline $\begin{array}{l}\text { Circulating potassium level, } \\
\text { low }{ }^{*} / \text { normal }\end{array}$ & $27 / 4$ \\
\hline
\end{tabular}

${ }^{\ddagger}$ Assessed exclusively in subjects with total calcium level $<2.20 \mathrm{mmol} / \mathrm{L}$. ${ }^{*}<3.5 \mathrm{mmol} / \mathrm{L}$.

duration of treatment with a proton-pump inhibitor was one year or more in all cases with the exception of a newborn baby with gastroesophageal reflux on lansoprazole, and 3 years or more in $75 \%$ of the cases. When measured, hypomagnesemia was always accompanied by hypomagnesiuria. Moreover, it was very often accompanied by blood calcium level $<2.20 \mathrm{mmol} / \mathrm{L}$ (97\%), low or normal parathyroid hormone levels (95\%), and blood potassium level $<3.50 \mathrm{mmol} / \mathrm{L}$ (87\%). Linear regression analysis did not show an association between the degree of hypomagnesemia with the degree of hypocalcemia or hypokalemia (Figure 2). Further possible causes of hypomagnesemia were observed in at least 21 cases: treatment with either thiazide $(N=7)$ or loop diuretic 


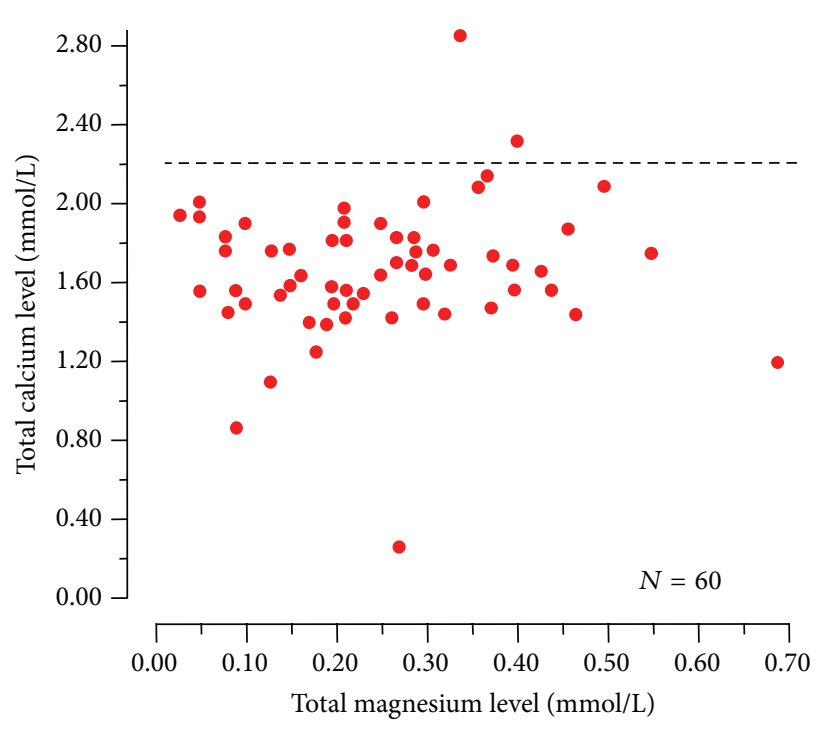

(a)

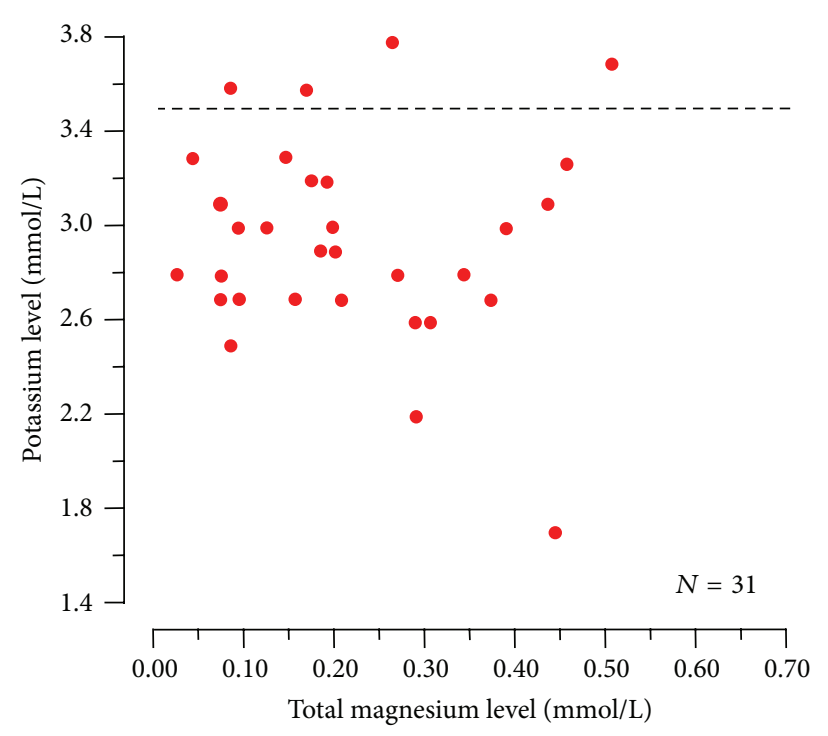

(b)

FIGURE 2: Relationship between circulating magnesium and total calcium (left panel) or potassium (right panel) in patients with proton-pump inhibitor associated hypomagnesemia. None of the correlations was found to be significant. The horizontal dotted lines denote the threshold level of hypocalcemia $(2.20 \mathrm{mmol} / \mathrm{L})$ and hypokalemia $(3.5 \mathrm{mmol} / \mathrm{L})$, respectively.

$(N=6)$, alcohol abuse $(N=5)$, poor renal function $(N=2)$, and small bowel resection $(N=1)$.

The following proton-pump inhibitors were used in the 64 patients: omeprazole, esomeprazole, the S-isomer of omeprazole, or both $(N=52)$; pantoprazole $(N=6)$; lansoprazole $(N=3)$; omeprazole and lansoprazole $(N=1)$; rabeprazole $(N=2)$. No cases of hypomagnesemia were reported on dexlansoprazole. Hypomagnesemia resolved after discontinuing the proton-pump inhibitor but recurred following replacement with another proton-pump inhibitor in at least 13 cases. In these cases, the initially used protonpump inhibitor was replaced as follows: with omeprazole or esomeprazole $(N=4)$; with lansoprazole $(N=3)$; with pantoprazole $(N=2)$; with esomeprazole and subsequently pantoprazole $(N=2)$; and with pantoprazole and subsequently lansoprazole $(N=2)$. In contrast, hypomagnesemia did not recur in 32 patients following switching to a histamine type-2 receptor antagonist: ranitidine $(N=29)$, famotidine $(N=2)$, and cimetidine $(N=1)$.

3.3. Case-Control, Cross-Sectional Studies. The association between proton-pump inhibitors and metabolism of magnesium was addressed in 14 case-control, cross-sectional studies, as given in Table 2. An association was found uniquely in 10 of them. Six reports found that the use of proton-pump inhibitors is associated per se with a tendency towards hypomagnesemia $[8,10,11,13,14,18]$. Two reports found that the tendency towards hypomagnesemia is more pronounced in patients concurrently treated with either diuretic $[13,18]$ or carboplatin and cisplatin [11]. Danziger et al. [7] found that hypomagnesemia occurs exclusively in patients concurrently taking diuretics. Furthermore, two reports found a relevant tendency to hypomagnesemia in patients with poor renal function treated with proton-pump inhibitors $[5,15]$.

William et al. [17] found an association between the use of proton-pump inhibitors and decreased urinary magnesium excretion (a finding that likely reflects a decreased intestinal magnesium uptake).

Finally, three of the aforementioned studies did not find any relationship between magnesium and histamine type- 2 receptor antagonists $[7,14,18]$.

3.4. United States Food and Drug Administration Data. The reports submitted to the Adverse Event Reporting System of the United States Food and Drug Administration were recently examined to address the association between use of proton-pump inhibitors and hypomagnesemia [63]. Between 1997 and 2012, 66,102 subjects were identified as experiencing at least one adverse effect while taking a proton-pump inhibitor. Among the mentioned subjects, $693(=1.0 \%)$ were reported to have hypomagnesemia. Subjects aged $\geq 65$ years were at increased risk of hypomagnesemia $(P<0.001)$. Finally, there was a strong $(P<0.001)$ association between occurrence of hypomagnesemia and that of hypocalcemia or hypokalemia. Two thirds $(N=461)$ of the hypomagnesemia cases occurred in subjects treated with omeprazole or esomeprazole, the most frequently prescribed proton-pump inhibitors.

\section{Discussion}

This work brings together the most recent literature and some reports identified exclusively from the search engine Google Scholar. Its results, acquired both in individual case reports and in case-control, cross-sectional studies, support the 
TABLE 2: Case-control, cross-sectional studies addressing the potential of proton-pump inhibitors to modulate the metabolism of magnesium. Reports disclosing a significant relationship between use of these drugs and metabolism of magnesium are bold.

\begin{tabular}{|c|c|c|c|}
\hline Reference & Country & Patients & Results \\
\hline Alhosaini et al. [5] & USA & 62 hemodialysis patients & $\begin{array}{l}\text { Use of proton-pump inhibitors was associated } \\
(\mathrm{P}<0.05) \text { with hypomagnesemia }\end{array}$ \\
\hline Biyik et al. [6] & Turkey & 238 outpatients & $\begin{array}{l}\text { Magnesemia was similar in users of proton-pump } \\
\text { inhibitors }(N=154) \text { and nonusers }(N=84)\end{array}$ \\
\hline Danziger et al. [7] & USA & $\begin{array}{l}11,490 \text { patients admitted } \\
\text { to an intensive care unit }\end{array}$ & $\begin{array}{l}\text { Hypomagnesemia was disclosed exclusively } \\
(\mathrm{P}<0.01) \text { in patients concurrently treated with both } \\
\text { proton-pump inhibitors and diuretics. Use of } \\
\text { histamine type-2 receptor antagonists (with or } \\
\text { without diuretics) was not associated with } \\
\text { hypomagnesemia }\end{array}$ \\
\hline $\begin{array}{l}\text { El-Charabaty et al. } \\
{[8]}\end{array}$ & USA & $\begin{array}{l}262 \text { intensive care patients } \\
\text { with cardiac arrhythmias }\end{array}$ & $\begin{array}{l}\text { Use of proton-pump inhibitors prior to admission } \\
\text { was associated with tendency to hypomagnesemia } \\
(\mathbf{r}=\mathbf{0 . 8 2})\end{array}$ \\
\hline Faulhaber et al. [9] & Brazil & $\begin{array}{l}151 \text { internal medicine } \\
\text { patients }\end{array}$ & $\begin{array}{l}\text { No cases of hypomagnesemia were detected on } \\
\text { treatment with proton-pump inhibitors }\end{array}$ \\
\hline Gau et al. [10] & USA & 487 inpatients & $\begin{array}{l}\text { Use of proton-pump inhibitors was associated with } \\
\text { lower magnesemia }(\mathrm{P}<0.005) \text { and with a } 2.5 \text {-fold } \\
\text { increased risk of hypomagnesemia }\end{array}$ \\
\hline Kim et al. [11] & Korea & 1356 patients & $\begin{array}{l}\text { Magnesemia was lower }(\mathrm{P}<0.0001) \text { in users of } \\
\text { proton-pump inhibitors }(\mathrm{N}=112) \text { than in nonusers } \\
(\mathrm{N}=1,244) \text {. Concurrent treatment with cisplatin } \\
(\mathrm{P}<0.05) \text { or carboplatin }(\mathrm{P}<0.01) \text { further } \\
\text { exacerbated hypomagnesemia }\end{array}$ \\
\hline $\begin{array}{l}\text { Koulouridis et al. } \\
{[12]}\end{array}$ & USA & $\begin{array}{l}804 \text { well-matched } \\
\text { inpatients }\end{array}$ & $\begin{array}{l}\text { Use of proton-pump inhibitors prior to admission was } \\
\text { not associated with hypomagnesemia }\end{array}$ \\
\hline Lindner et al. [13] & Switzerland & $\begin{array}{l}5,118 \text { emergency } \\
\text { department patients }\end{array}$ & $\begin{array}{l}\text { Hypomagnesemia was significantly }(\mathrm{P}<0.0001) \\
\text { associated with the use of proton-pump inhibitor or } \\
\text { both proton-pump inhibitors and diuretics }\end{array}$ \\
\hline $\begin{array}{l}\text { Markovits et al. } \\
{[14]}\end{array}$ & Israel & 95,205 outpatients & $\begin{array}{l}\text { Users of proton-pump inhibitors }(\mathrm{N}=22,458) \\
\text { presented frequently with hypomagnesemia } \\
(\mathrm{P}<0.005) \text {. Use of histamine type-2 receptor } \\
\text { antagonists was not associated with hypomagnesemia }\end{array}$ \\
\hline $\begin{array}{l}\text { Sumukadas et al. } \\
{[15]}\end{array}$ & $\begin{array}{c}\text { United } \\
\text { Kingdom }\end{array}$ & 196 elderly unit patients & $\begin{array}{l}\text { Magnesemia was lower }(P<0.05) \text { in users of } \\
\text { proton-pump inhibitors with poor renal function }\end{array}$ \\
\hline Van Ende et al. [16] & Belgium & $\begin{array}{l}512 \text { renal transplant } \\
\text { recipients }\end{array}$ & $\begin{array}{l}\text { Use of proton-pump inhibitors was not a predictor of } \\
\text { hypomagnesemia }\end{array}$ \\
\hline William et al. [17] & USA & 278 outpatients & $\begin{array}{l}\text { Magnesiuria was reduced }(P<0.02) \text { in users of } \\
\text { proton-pump inhibitors. Diuretics did not modulate } \\
\text { the effect of proton-pump inhibitors on magnesiuria }\end{array}$ \\
\hline Zipursky et al. [18] & Canada & 1,830 inpatients & $\begin{array}{l}\text { Patients admitted with hypomagnesemia were } \\
\text { frequently (odds ratio }=1.43 \text { ) on proton-pump } \\
\text { inhibitors. Diuretics further exacerbated the } \\
\text { tendency to hypomagnesemia (odds ratio }=1.73 \text { ). Use } \\
\text { of histamine type-2 receptor antagonists was not } \\
\text { associated with hypomagnesemia }\end{array}$ \\
\hline
\end{tabular}
associated with hypomagnesemia

hypothesis that management with proton-pump inhibitors may cause hypomagnesemia along with hypomagnesiuria, hypocalcemia, and hypokalemia (see the following list). This tendency is more pronounced in patients concomitantly treated with cisplatin, carboplatin, and especially diuretics and in those with poor renal function.
Clinical and Biochemical Characteristics of Proton-Pump Inhibitor Associated Hypomagnesemia. Consider the following.

(i) Age mostly $\geq 50$ years, duration of treatment $\geq 1$ year, and no emblematical patient profile unique for 
this electrolyte abnormality, being more frequent in patients concurrently managed with other factors that may lower magnesemia (e.g., management with thiazides and loop diuretics, alcohol abuse) and in those with poor renal function.

(ii) Hypomagnesemia often accompanied by hypocalcemic hypoparathyroidism and hypokalemia.

(iii) Hypomagnesemia resolution soon after discontinuing the proton-pump inhibitor, recurring upon readministration or after replacement of one protonpump inhibitor with another (=class effect).

(iv) Hypomagnesemia not occurring with histamine type-2 receptor antagonists (e.g., ranitidine).

The concurrent demonstration of both magnesium deficiency and hypomagnesiuria suggests that impaired intestinal magnesium absorption is the culprit. This electrolyte abnormality recovers within 4 days after discontinuing the drug; it recurs upon readministration or after replacement with another proton-pump inhibitor [64], but it does not develop with other acid suppressants such as histamine type-2 receptor antagonists. Hypomagnesemia was mostly accompanied by hypocalcemia and normal or low parathyroid hormone levels, confirming the existence of a state of secondary hypoparathyroidism in the most severely hypomagnesemic patients [65]. A further common laboratory finding was hypokalemia, a recognized consequence of hypomagnesemia [65].

In the few individual cases available for such an analysis, no significant correlation was noted between circulating magnesium and hypocalcemia or hypokalemia. At least two factors might account for this unexpected observation. First, there are sometimes differences among laboratories with respect to total magnesium determination in blood [65]. Furthermore, circulating magnesium exists in the ionized, biologically active state and in the undissociated form, either bound to albumin or complexed to anions such as bicarbonate, citrate, and phosphate [65].

At least three limitations of our study should be mentioned. First, the analysis results rather from the small number of reported subjects affected by proton-pump inhibitor associated hypomagnesemia. Second, because of the scant information available on the clinical presentation of magnesium deficiency, the present study does not address this issue. Third, the underlying mechanisms require further investigations.

Recognition and management of hypomagnesemia secondary to long-term treatment with proton-pump inhibitors mainly rest on two pillars: first, blood magnesium monitoring at least in patients with symptoms or signs consistent with magnesium deficiency, in those concurrently treated with other agents that may lower magnesium level, and in those with poor renal function; second, in patients with hypomagnesemia, switching to a histamine type- 2 receptor antagonist may be attempted. Further studies are required to identify whether magnesium supplements or sucralfate might be prescribed in subjects with proton-pump inhibitor associated hypomagnesemia.

\section{Disclosure}

The authors have no financial relationships relevant to this paper to disclose.

\section{Conflict of Interests}

The authors declare that there is no potential conflict of interests.

\section{Authors' Contribution}

Simone Janett, the principal investigator, conceptualized and designed the study, performed the review of the literature, drafted the initial paper, and approved the final paper as submitted. Pietro Camozzi conceptualized and designed the study, performed the review of the literature, designed the figures, and approved the final paper as submitted. Gabriëlla G. A. M. Peeters conceptualized the study, substantially participated in the review of the literature, and approved the final paper as submitted. Sebastiano A. G. Lava contributed to the study design, supervised the review of the literature, prepared the figures, and wrote the final paper as submitted. Giacomo D. Simonetti and Barbara Goeggel Simonetti supervised the review of the literature and approved the final paper as submitted. Mario G. Bianchetti, the senior author, conceptualized and designed the study, supervised the review of the literature and the preparation of the paper, performed statistical analysis, and wrote the final paper as submitted. Gregorio P. Milani conceptualized and designed the study, supervised the review of the literature, the statistical analysis, and wrote the final paper as submitted. Simone Janett and Pietro Camozzi contributed equally to this work.

\section{References}

[1] M. Robinson and J. Horn, "Clinical pharmacology of protonpump inhibitors: what the practising physician needs to know," Drugs, vol. 63, no. 24, pp. 2739-2754, 2003.

[2] M. Epstein, S. McGrath, and F. Law, "Proton-pump inhibitors and hypomagnesemic hypoparathyroidism," The New England Journal of Medicine, vol. 355, no. 17, pp. 1834-1836, 2006.

[3] T. Cundy and J. MacKay, "Proton pump inhibitors and severe hypomagnesaemia," Current Opinion in Gastroenterology, vol. 27, no. 2, pp. 180-185, 2011.

[4] F. Sierra, M. Suarez, M. Rey, and M. F. Vela, "Systematic review: proton pump inhibitor-associated acute interstitial nephritis," Alimentary Pharmacology and Therapeutics, vol. 26, no. 4, pp. 545-553, 2007.

[5] M. Alhosaini, J. S. Walter, S. Singh, R. S. Dieter, A. Hsieh, and D. J. Leehey, "Hypomagnesemia in hemodialysis patients: role of proton pump inhibitors," American Journal of Nephrology, vol. 39, no. 3, pp. 204-209, 2014.

[6] M. Biyik, Y. Solak, R. Ucar et al., "Hypomagnesemia among outpatient long-term proton pump inhibitor users," American Journal of Therapeutics, 2014.

[7] J. Danziger, J. H. William, D. J. Scott et al., "Proton-pump inhibitor use is associated with low serum magnesium concentrations," Kidney International, vol. 83, no. 4, pp. 692-699, 2013. 
[8] E. El-Charabaty, C. Saifan, M. Abdallah et al., "Effects of proton pump inhibitors and electrolyte disturbances on arrhythmias," International Journal of General Medicine, vol. 6, pp. 515-518, 2013.

[9] G. A. M. Faulhaber, B. M. Ascoli, A. Lubini et al., "Serum magnesium and proton-pump inhibitors use: a cross-sectional study," Revista da Associação Médica Brasileira, vol. 59, no. 3, pp. 276-279, 2013.

[10] J.-T. Gau, Y.-X. Yang, R. Chen, and T.-C. Kao, "Uses of protonpump inhibitors and hypomagnesemia," Pharmacoepidemiology and Drug Safety, vol. 21, no. 5, pp. 553-559, 2012.

[11] S. Kim, H. Lee, C. H. Park et al., "Clinical predictors associated with proton-pump Inhibitor-induced hypomagnesemia," The American Journal of Therapeutics, vol. 22, pp. 14-21, 2015.

[12] I. Koulouridis, M. Alfayez, H. Tighiouart et al., "Out-of-hospital use of proton pump inhibitors and hypomagnesemia at hospital admission: a nested case-control study," American Journal of Kidney Diseases, vol. 62, no. 4, pp. 730-737, 2013.

[13] G. Lindner, G.-C. Funk, A. B. Leichtle et al., "Impact of proton pump inhibitor use on magnesium homoeostasis: a cross-sectional study in a tertiary emergency department," International Journal of Clinical Practice, vol. 68, no. 11, pp. 13521357, 2014.

[14] N. Markovits, R. Loebstein, H. Halkin et al., "The association of proton pump inhibitors and hypomagnesemia in the community setting," The Journal of Clinical Pharmacology, vol. 54, no. 8, pp. 889-895, 2014.

[15] D. Sumukadas, M. E. T. McMurdo, and D. Habicht, "Proton pump inhibitors are associated with lower magnesium levels in older people with chronic kidney disease," Journal of the American Geriatrics Society, vol. 60, no. 2, pp. 392-393, 2012.

[16] C. Van Ende, S. van Laecke, C. Marechal et al., "Proton-pump inhibitors do not influence serum magnesium levels in renal transplant recipients," Journal of Nephrology, vol. 27, no. 6, pp. 707-711, 2014.

[17] J. H. William, R. Nelson, N. Hayman, K. J. Mukamal, and J. Danziger, "Proton-pump inhibitor use is associated with lower urinary magnesium excretion," Nephrology, vol. 19, no. 12, pp. 798-801, 2014.

[18] J. Zipursky, E. M. Macdonald, S. Hollands et al., "Proton pump inhibitors and hospitalization with hypomagnesemia: a population-based case-control study," PLoS Medicine, vol. 11, no. 9, Article ID e1001736, 2014.

[19] O. Amatruda, "A misleading, underestimated side effect of a commonly used therapy. Following your stomach may hurt your heart," Journal of Medicine and the Person, vol. 8, pp. 3133, 2010.

[20] N. Arulanantham, M. Anderson, N. Gittoes, and R. E. Ferner, "A 63-year-old man with hypomagnesaemia and seizures," Clinical Medicine, vol. 11, no. 6, pp. 591-593, 2011.

[21] J. Ayuk and N. J. L. Gittoes, "How should hypomagnesaemia be investigated and treated?" Clinical Endocrinology, vol. 75, no. 6, pp. 743-746, 2011.

[22] J. Ayuk and N. J. L. Gittoes, “Treatment of hypomagnesemia," The American Journal of Kidney Diseases, vol. 63, no. 4, pp. 691695, 2014.

[23] F. J. Basterra-Gortari, M. J. Goñi Iriarte, M. Toni García, and A. Iriarte Beroiz, "Hipoparatiroidismo hipomagnesémico asintomático inducido por pantoprazol," Medicina Clínica, vol. 137, no. 11, pp. 524-525, 2011.
[24] M. A. Broeren, E. A. Geerdink, H. L. Vader, and A. W. van den Wall Bake, "Hypomagnesemia induced by several proton-pump inhibitors," Annals of Internal Medicine, vol. 151, pp. 755-756, 2009.

[25] A. C. Díaz, E. M. Hernández, M. G. Navarro, P. Tutor-Ureta, M. Y. Bango, and J. A. V. Núñez, "Omeprazole and hypomagnesemia," Revista Clinica Espanola, vol. 211, no. 6, pp. e30-e33, 2011.

[26] P. Camozzi, S. Janett, and M. G. Bianchetti, "Un'insolita ammucchiata diselettrolitemica," Tribuna Medica Ticinese, vol. 79, pp. 155-157, 2014.

[27] M. Cano Megías, R. Álvarez Santirso, P. Iglesias Lozano, M. Carrasco de la Fuente, and G. Pérez López, "Hipomagnesemia relacionada con el uso de inhibidores de la bomba de protones, diarrea e intolerancia a lactosa," Endocrinología y Nutrición, vol. 58, no. 10, pp. 550-554, 2011.

[28] S. R. Choi, J. H. Byun, A. R. Kwon et al., "Proton-pump inhibitor-induced hypocalcemia and hypomagnesemia," Annals of Pediatric Endocrinology \& Metabolism, vol. 7, pp. 249-252, 2012.

[29] T. Cundy and A. Dissanayake, "Severe hypomagnesaemia in long-term users of proton-pump inhibitors," Clinical Endocrinology, vol. 69, no. 2, pp. 338-341, 2008.

[30] A. Deroux, C. Khouri, O. Chabre, L. Bouillet, and O. Casez, "Severe acute neurological symptoms related to proton pump inhibitors induced hypomagnesemia responsible for profound hypoparathyroidism with hypocalcemia," Clinics and Research in Hepatology and Gastroenterology, vol. 38, pp. 103-105, 2014.

[31] J. Doornebal, R. Bijlsma, and R. M. Brouwer, "Een onbekende, maar potentieel ernstige bijwerking van protonpompremmers: hypomagnesiëmie," Nederlands Tijdschrift voor Geneeskunde, vol. 153, article A711, 2009.

[32] G. Famularo, G. Minisola, M. C. Bravi, P. Colucci, and L. Gasbarrone, "Tetany, hypomagnesemia, and proton-pump inhibitors," The American Journal of Medicine, vol. 125, no. 10, pp. e7-e8, 2012.

[33] F. J. Fernández-Fernández, P. Sesma, T. Caínzos-Romero, and L. Ferreira, "Hipomagnesemia asociada a tratamiento con omeprazol y test genético negativo para mutación en TRPM6," Medicina Clínica, vol. 137, no. 4, pp. 188-189, 2011.

[34] F. J. Fernández-Fernández, P. Sesma, T. Caínzos-Romero, and L. Ferreira-González, "Intermittent use of pantoprazole and famotidine in severe hypomagnesaemia due to omeprazole," Netherlands Journal of Medicine, vol. 68, no. 10, pp. 329-330, 2010.

[35] M. François, N. Lévy-Bohbot, J. Caron, and V. Durlach, "Prise chronique d'inhibiteurs de la pompe à protons associée à une giardiase: une cause rare d'hypoparathyroïdisme hypomagnésémique?" Annales d'Endocrinologie, vol. 69, no. 5, pp. 446-448, 2008.

[36] C. Fumeaux, J. Schmidtko, and P. Meier, "Hypomagnésémie et inhibiteurs de la pompe à protons," Revue Medicale Suisse, vol. 8, no. 336, pp. 806-810, 2012.

[37] T. W. Furlanetto and G. A. M. Faulhaber, "Hypomagnesemia and proton pump inhibitors: below the tip of the iceberg," Archives of Internal Medicine, vol. 171, no. 15, pp. 1391-1392, 2011.

[38] N. Y. Gandhi, W. K. Sharif, S. Chadha, and J. Shakher, "A patient on long-term proton-pump inhibitors develops sudden seizures and encephalopathy: an unusual presentation of hypomagnesaemia," Case Reports in Gastrointestinal Medicine, vol. 2012, Article ID 632721, 4 pages, 2012. 
[39] A. G. Diez, J. G. C. Soriano, and I. M. Escudero, "Hipomagnesemia grave debida a tratamiento prolongado con omeprazol," Medicina Clínica, vol. 136, no. 2, pp. 84-85, 2011.

[40] A. Gutiérrez Macías, J. Ibarmia Lahuerta, M. Á. de Castro, and E. Lizarralde Palacios, "Hipomagnesemia grave en relación con omeprazol," Revista Clínica Española, vol. 211, pp. 488-489, 2011.

[41] W. Habeichi and G. Ahmed, "A case of severe hypocalcemia," The Ulster Medical Journal, vol. 82, pp. 124-125, 2013.

[42] C. Hmu, P. Moulik, and A. Macleod, "Severe hypomagnesaemia due to lansoprazole," BMJ Case Reports, 2009.

[43] E. J. Hoorn, J. van der Hoek, R. A. de Man, E. J. Kuipers, C. Bolwerk, and R. Zietse, "A case series of proton-pump inhibitorinduced hypomagnesemia," American Journal of Kidney Diseases, vol. 56, no. 1, pp. 112-116, 2010.

[44] L. Z. Krupa and I. W. Fellows, "Lansoprazole-induced hypomagnesaemia," BMJ Case Reports, 2014.

[45] M. T. Kuipers, H. D. Thang, and A. B. Arntzenius, "Hypomagnesaemia due to use of proton pump inhibitors-a review," Netherlands Journal of Medicine, vol. 67, no. 5, pp. 169-172, 2009.

[46] A. Lefort, P. Arlet, H. Bagheri, and E. Campistron, "Hypomagnésémie avec hypocalcémie sous oméprazole," Thérapie, vol. 67, no. 2, pp. 191-192, 2012.

[47] J. D. Mackay and P. T. Bladon, "Hypomagnesaemia due to proton-pump inhibitor therapy: a clinical case series," QJM, vol. 103, no. 6, pp. 387-395, 2010.

[48] J. Matsuyama, K. Tsuji, H. Doyama et al., "Hypomagnesemia associated with a proton pump inhibitor," Internal Medicine, vol. 51, no. 16, pp. 2231-2234, 2012.

[49] G. Miltiadous and M. Elisaf, "Acid-base balance-electrolyte quiz-case 2," Archives of Hellenic Medicine, vol. 28, p. 428, 2012.

[50] B. Nand and M. Bhagat, "Serious and commonly overlooked side effect of prolonged use of PPI," The American Journal of Medicine, vol. 127, no. 9, article e5, 2014.

[51] A. L. Negri and E. E. Valle, "Hypomagnesaemia/hypokalemia associated with the use of esomeprazole," Current Drug Safety, vol. 6, no. 3, pp. 204-206, 2011, Erratum in Current Drug Safety, vol. 8, no. 1, p. 75, 2013.

[52] M. O. Perez, E. F. Neves, C. B. Bortolai, P. D. Sampaio-Barros, D. C. Andrade, and L. P. Seguro, "Hypomagnesaemia and hypocalcaemia in a patient with systemic sclerosis: role of proton pump inhibitors," Clinical and Experimental Rheumatology, vol. 32, supplement 86, pp. 225-227, 2014.

[53] V. Piezzi, G. Kullak-Ublick, and P. Glisenti, "78-jährige Patientin mit Unwohlsein, Schwindel, Apraxie und Krampfanfall unter Protonenpumpeninhibitortherapie," Der Internist, vol. 55, no. 2, pp. 199-205, 2014.

[54] M. Quasdorff, J. Mertens, J. Dinter, and H.-M. Steffen, "Recurrent hypomagnesemia with proton-pump inhibitor rechallenge," Annals of Internal Medicine, vol. 155, no. 6, pp. 405-407, 2011.

[55] G. Regolisti, A. Cabassi, E. Parenti, U. Maggiore, and E. Fiaccadori, "Severe hypomagnesemia during long-term treatment with a proton-pump inhibitor," The American Journal of Kidney Diseases, vol. 56, no. 1, pp. 168-174, 2010.

[56] J. Schor, O. Ghabra, and M. Sekkarie, "Proton pump inhibitor induced hypomagnesemia: a case report," The Journal of Supportive Oncology, vol. 11, no. 2, p. 103, 2013.

[57] N. Shabajee, E. J. Lamb, I. Sturgess, and R. W. Sumathipala, "Omeprazole and refractory hypomagnesaemia.," The British Medical Journal, vol. 337, article a425, 2008.
[58] E. Ströker, L. Leone, Y. Vandeput, I. Borbath, and C. Lefebvre, "Severe symptomatic hypomagnesaemia induced by the chronic use of proton pump inhibitors: a case report of a patient with Zollinger-Ellison syndrome," acta Clinica Belgica, vol. 69, no. 1, pp. 62-65, 2014.

[59] K. Swaminathan and J. Wilson, "Elusive cause of hypomagnesaemia," British Medical Journal, vol. 343, no. 7830, Article ID d5087, 2011.

[60] J. W. Toh, E. Ong, and R. Wilson, "Hypomagnesaemia associated with long-term use of proton pump inhibitors," Gastroenterology Report (Oxford), 2014.

[61] M. Turnock, C. Pagnoux, and K. Shore, "Severe hypomagnesemia and electrolyte disturbances induced by proton pump inhibitors," Journal of Digestive Diseases, vol. 15, no. 8, pp. 459462, 2014.

[62] A. K. Wang, S. Sharma, P. Kim, and K. Mrejen-Shakin, "Hypomagnesemia in the intensive care unit: choosing your gastrointestinal prophylaxis, a case report and review of the literature," Indian Journal of Critical Care Medicine, vol. 18, no. 7, pp. 456-460, 2014.

[63] C. P. Luk, R. Parsons, Y. P. Lee, and J. D. Hughes, "Proton pump inhibitor-associated hypomagnesemia: what do FDA data tell us?" Annals of Pharmacotherapy, vol. 47, no. 6, pp. 773-780, 2013.

[64] M. W. Hess, J. G. J. Hoenderop, R. J. M. Bindels, and J. P. H. Drenth, "Systematic review: hypomagnesaemia induced by proton pump inhibition," Alimentary Pharmacology and Therapeutics, vol. 36, no. 5, pp. 405-413, 2012.

[65] E. J. Hoorn and R. Zietse, "Disorders of calcium and magnesium balance: a physiology-based approach," Pediatric Nephrology, vol. 28, no. 8, pp. 1195-1206, 2013. 


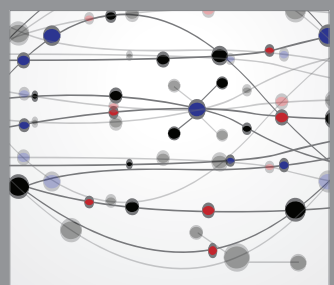

The Scientific World Journal
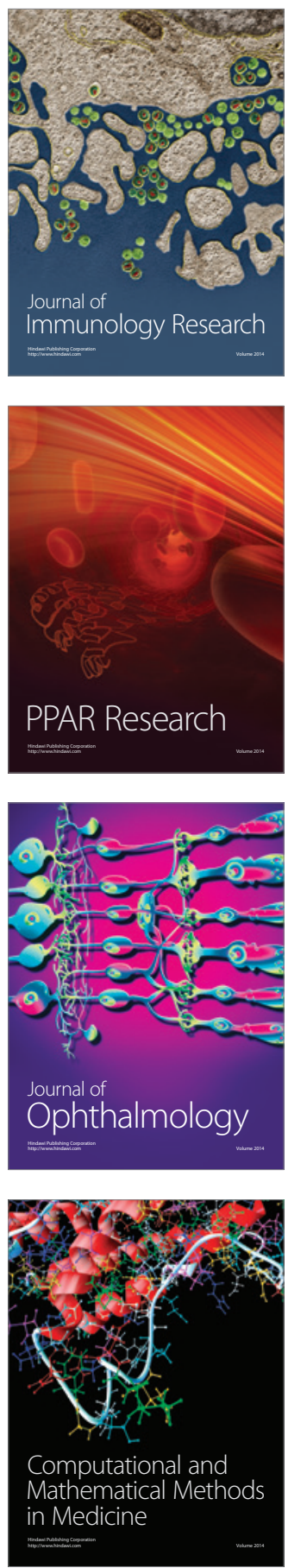

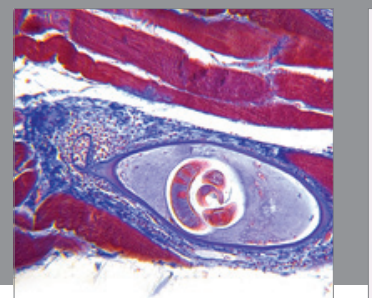

Gastroenterology

Research and Practice
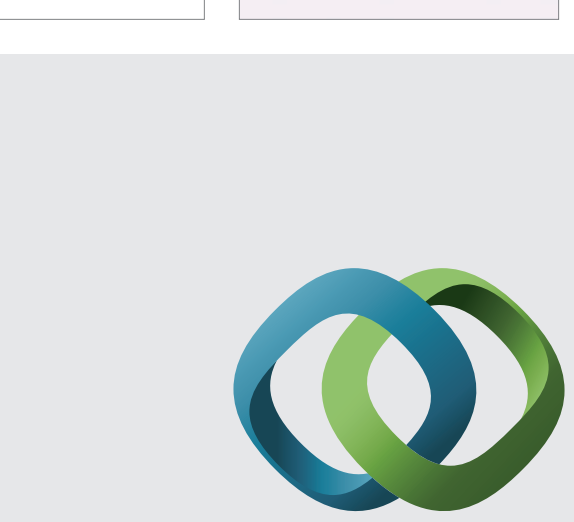

\section{Hindawi}

Submit your manuscripts at

http://www.hindawi.com
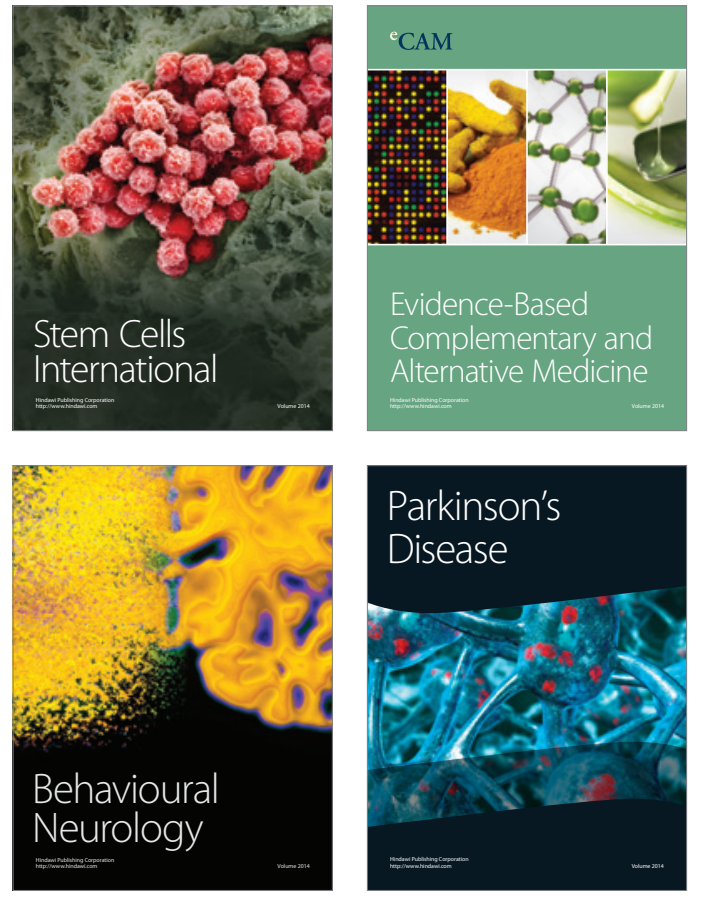
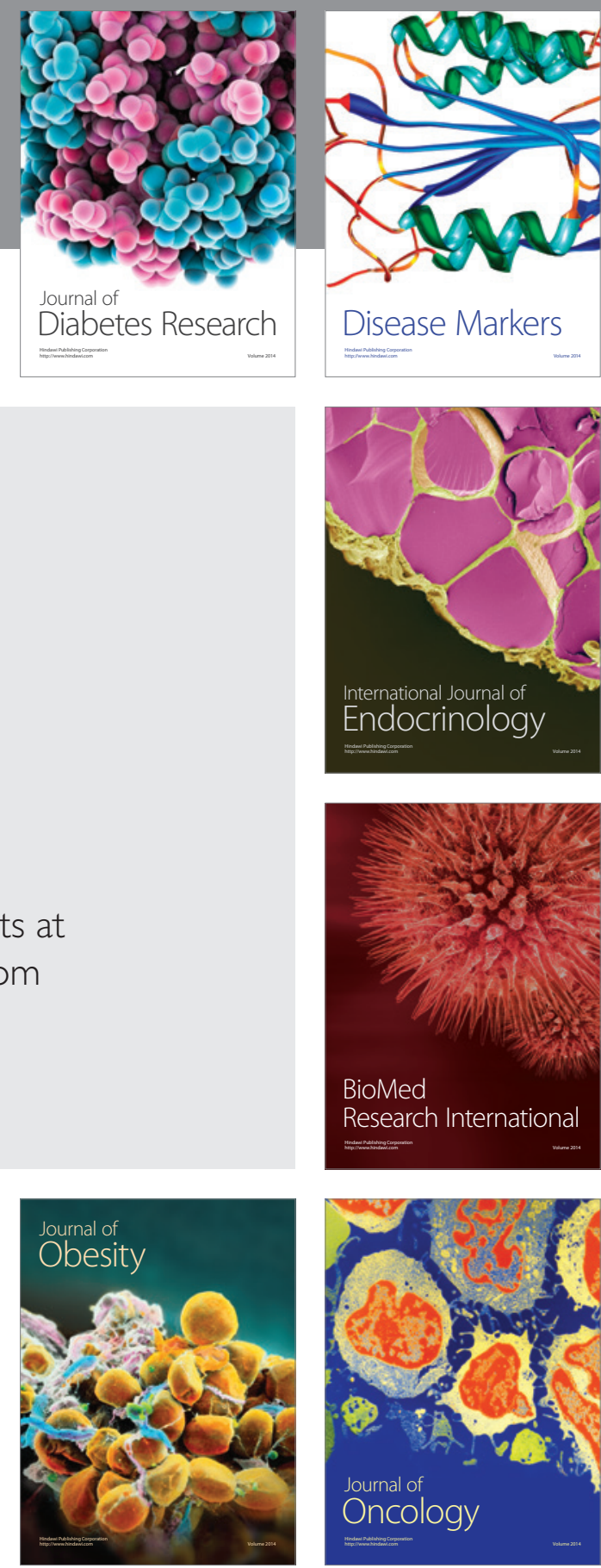

Disease Markers
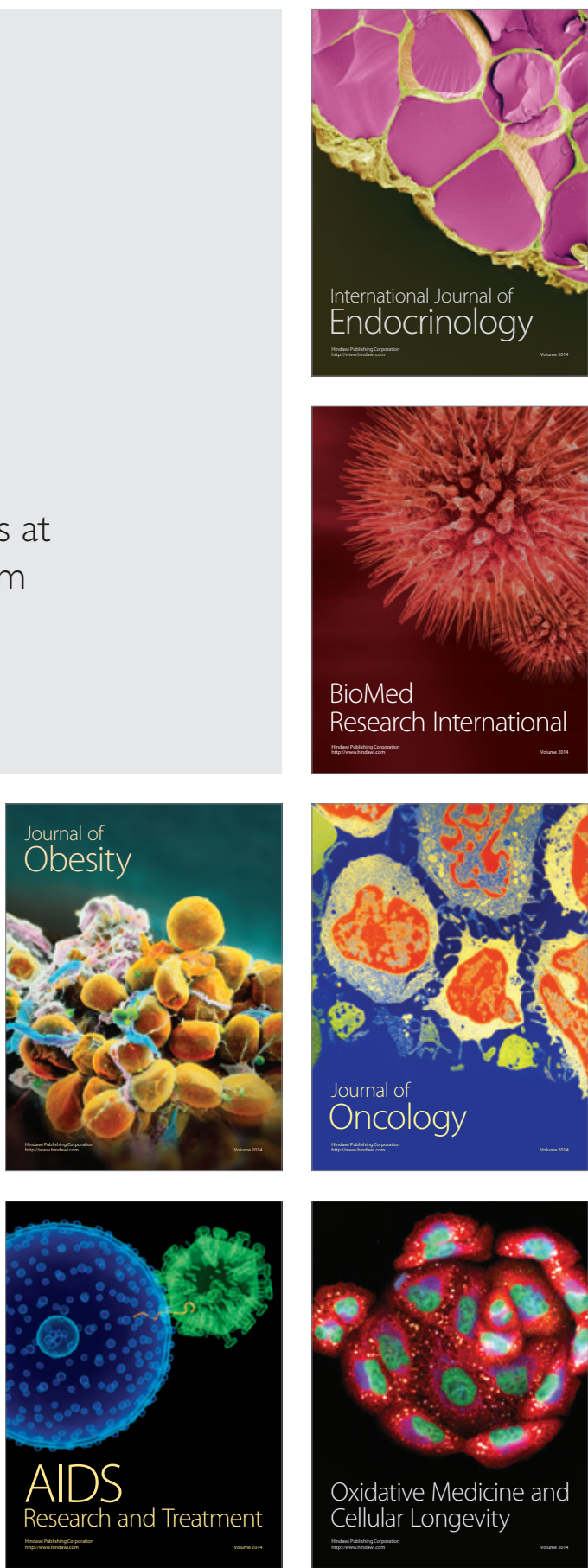